\title{
Assessment of physicochemical and bacteriological groundwater quality in irrigated Triffa Plain, North-East of Morocco
}

\author{
Mohammed KADAOUI ${ }^{1 \text { ABCDEF }}{ }^{凶}$, Abderrahime BOUALI ${ }^{1) \text { ACDEF }}$, \\ Mourad ARABI ${ }^{2)}$ F
}

\footnotetext{
${ }^{1)}$ University Mohammed Premier, Faculty of Sciences, Laboratory of Genetics and Biotechnologies, BV Mohammed VI B.P. 524, Oujda 60000, Morocco; e-mail: kadamed2012@gmail.com

2) University Mohammed Premier, Faculty of Sciences, Laboratory of Water Sciences, Ecology, and Sustainable Development, Oujda, Morocco; e-mail: mourad.arabi.svi@gmail.com
}

For citation: Kadaoui M., Bouali A., Arabi M. 2019. Assessment of physicochemical and bacteriological groundwater quality in irrigated Triffa Plain, North-East of Morocco. Journal of Water and Land Development. No. 42 (VII-IX) p. 100-109. DOI: 10.2478/jwld-2019-0050.

\begin{abstract}
The physicochemical and bacteriological quality of groundwater was assessed to show the impact of the agriculture and human activities in the Triffa Plain located in North-East of Morocco. The current levels of contamination of the groundwater were estimated by analysing electrical conductivity, nitrate, nitrite, ammonia, orthophosphate, and indicators of faecal pollution content.

Water samples from 55 locations were collected during two period of time, the wet and the dry season of the year 2016. Result obtained indicated that most samples are highly contaminated. The electrical conductivity varied from 800 to 9100 $\mu \mathrm{S} \cdot \mathrm{cm}^{-1}$. Nitrate levels ranged from 25 to $216 \mathrm{mg} \cdot \mathrm{dm}^{-3}$, with $78 \%$ of samples exceeding the critical level value set at 50 $\mathrm{mg} \cdot \mathrm{dm}^{-3}$. Nitrate concentrations are slightly higher during the wet period in $73 \%$ of studied cases. Nitrite rarely exceeded the normal rate fixed by World Health Organization and reached $0.90 \mathrm{mg} \cdot \mathrm{dm}^{-3}$. Ammonia and orthophosphate contents do not exceed these norms.

The study revealed a wide contamination of groundwater by microbial agents such as, total coliforms, faecal coliforms and faecal streptococci, with content ranged from 0 to 14000,0 to 5000 and 0 to $5000 \mathrm{CFU} \cdot\left(100 \mathrm{~cm}^{3}\right)^{-1}$ respectively, confirming the impact of septic tanks, wastewater discharge into rivers without treatment, and the use of animal waste on the ground water vulnerability.

Samplings and measurements were carried out according to the international standard ISO 13395, ISO 11732 and ISO 15681-2 for chemical compounds and ISO 9308-1 and ISO 7899-2 for microbiological numerations.
\end{abstract}

Key words: agriculture, bacteriological quality, groundwater, physicochemical quality, Triffa Plain, wastewater

\section{INTRODUCTION}

In Morocco, the surface water resources are estimated to ac. $19 \cdot 10^{9} \mathrm{~m}^{3}$ per year, while for groundwater resources, with nearly 80 identified underground aquifers, the volume is estimated at ca. $4 \cdot 10^{9} \mathrm{~m}^{3}$ per year [BZIOUI 2004]. Morocco is classified among water-stressed countries with large drought period. The national averaged available water resources are estimated to be $750 \mathrm{~m}^{3}$ per inhabitant per year. Add to that the qualitative degradation is threatening furthermore these resources [MEMEE 2014] and destroy the hydraulic heritage of the country [MATEE 2001], which constitutes the water privileged resources for drinking water.

Irrigated agriculture is responsible for $93 \%$ of the total consumed water in Morocco. It is also the principal driver for ensuring food security and economic development [EL HAMMOUMI et al. 2013]. Yet, intensive agriculture in irri- 
gated areas is responsible for the release of pollutants to the groundwater [LAFTOUHI et al. 2003]. Indeed, the fiscal benefits granted to farmers since 1985 , encourages strongly agricultural intensification. The irrigated areas, which represent only $12 \%$ of the useful agricultural area of the country, consume more than $50 \%$ of fertilizer inputs at the national level [FETOUANI et al. 2008].

Water is essential for life. However, it can also be a source of diseases [EL HAISSOUFI et al. 2011], because it can play the role of vector of potentially harmful agents, such as pathogenic microorganisms and chemical compounds [HASSOUNE et al. 2010; KELMENDI et al. 2018]. The daily absorption of large quantities of nitrate contained in the drinking water, may cause public health problems such as the appearance of certain cancers [WEYER et al. 2001], or infant methemoglobinemia [AVERY 2001; FREISHTAT et al. 2005; VENKATESWARI et al. 2007]. In Moroc$\mathrm{co}$, the use of groundwater from unprotected public or private wells, with the insufficiency of the sewage network and ignorance in the sense of hygienic rules facilitates the rise of certain diseases such as hepatitis and typhoid [HASSOUNE et al. 2006; MELlOUL et al. 2002]. In the Triffa Plain located in the North-East of Morocco, the pressures, and the practices of intensive irrigated agriculture, and the discharge of wastewater into rivers, have negative impacts on groundwater quality [BENKADDOUR 1997; FEKKOUL et al. 2013; FETOUANI et al. 2008; YAHYA et al. 2015]. Here, we report the assessment of groundwater quality using physicochemical and bacteriological analysis. We show the current levels of groundwater contamination with salinity, nitrates, nitrites, ammonium, and orthophosphates. These compounds are in direct relation with agricultural practices. Also we determine the degree of microbiological pollution caused by septic tanks.

\section{MATERIAL AND METHODS}

\section{STUDY AREA}

The Triffa Plain is the most productive irrigated agricultural area in north-eastern Morocco with an area of ca. $750 \mathrm{~km}^{2}$ (Fig. 1A). It is limited in the North toward the Mediterranean Sea by Ouled Mansour hills, in the South by Beni Snassen Mountains, in the West by the Moulouya River and its affluent the Cheraa River, and in the East by the Kiss River, along the Moroccan-Algerian border. In Triffa Plain there are two aquifers (Fig. 1B), a shallow aquifer of the secondary and quaternary formations, and a deep aquifer of the Liassic formations [BoUGHRIBA, JILALI 2018]. The Triffa syncline is developed during secondary and quaternary geological formations. The quaternary formations cover almost the whole surface of the plain. The upper aquifer is unconfined, heterogeneous and composed of many lithological facies: sandstone, limestone, silt, clay, conglomerates and calcareous sandstone [FetouAni et al. 2008]. The flow direction is from SouthEast to North-West [EL MANDOUR 1998].

The region's climate is Mediterranean, semi-arid with long dry periods with an average annual rainfall of ca. 300 $\mathrm{mm}$ and the average annual evapotranspiration of ca. 300 mm per year [FEKKOUL et al. 2013].

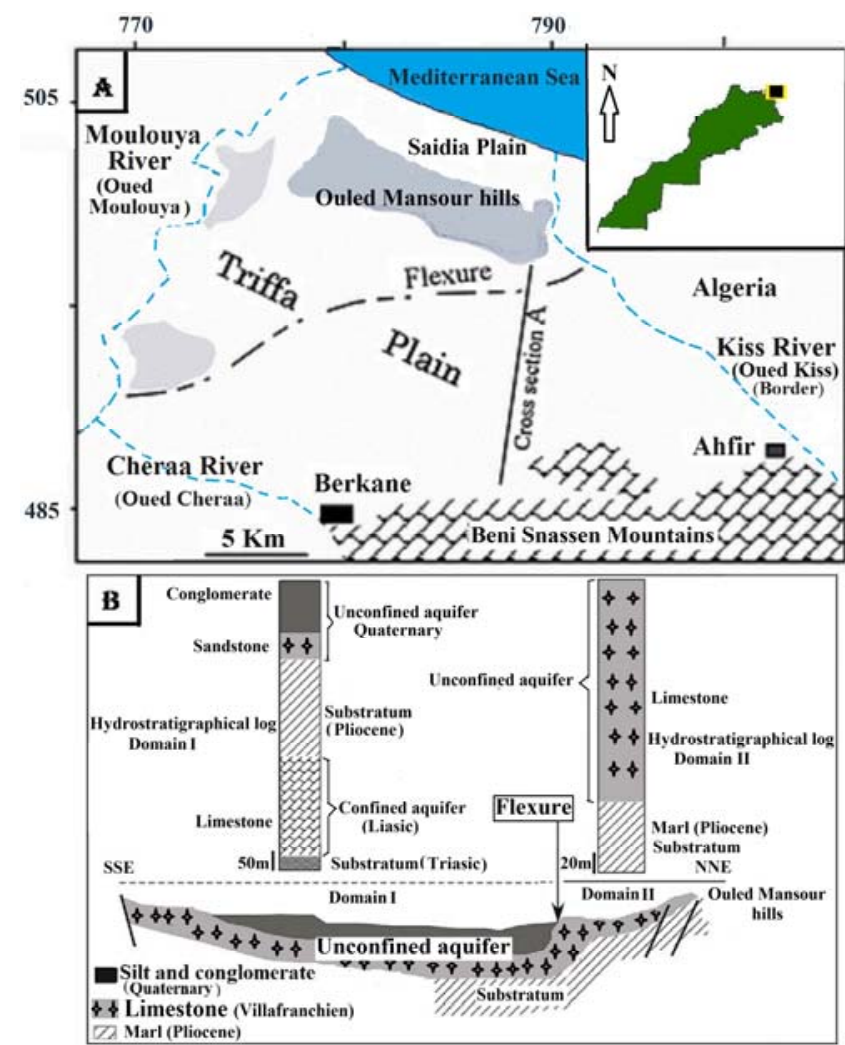

Fig. 1. Study area: A) location, B) the North-South hydrogeological cross-section of Triffa Plain; source: FEKKOUL et al. [2013], modified

\section{SAMPLING STRATEGY AND WATER ANALYSIS}

Fifty-five ground water samples (51 wells and 4 springs: Titilila (S8), Ain-Beida (S17), Ain-Zerga (S18), Ain-Zebda (S21)) spread over the study area (Fig. 2). All wells were dug manually and are fed from the unconfined

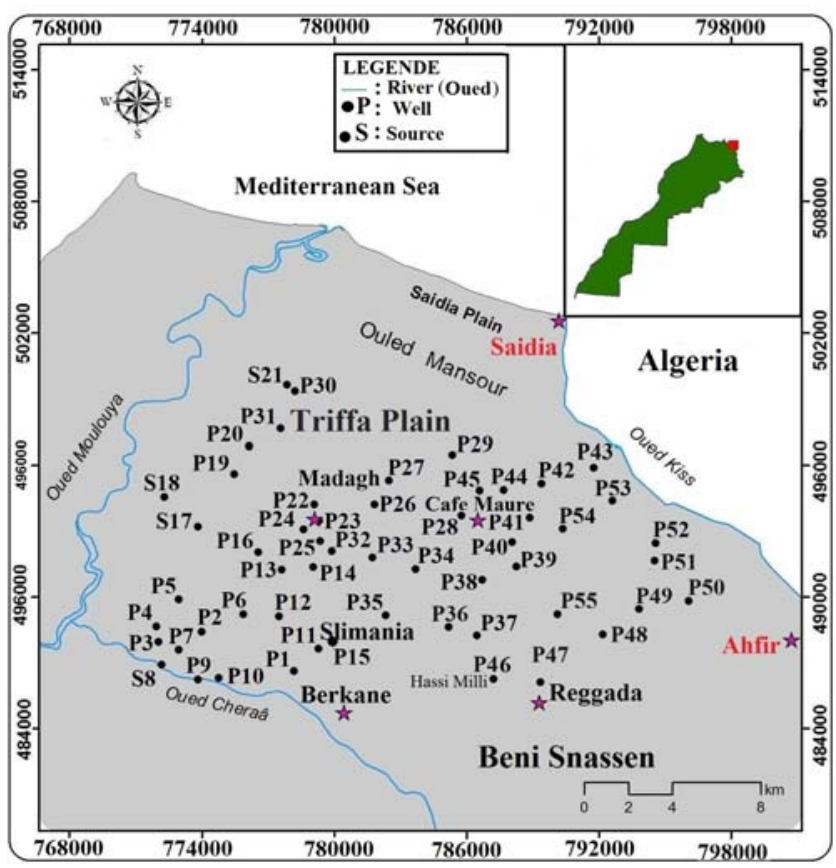

Fig. 2. Sampling locations in Triffa Plain; source: own elaboration 
aquifer. Their depth to water level varies between $2 \mathrm{~m}$ (in centre part of plain (Madagh)) and $65 \mathrm{~m}$ below ground surface (in South of the plain).

Water salinity of wells P30, P35 and spring S21 are high, and could increase dramatically during a drought. Consequently their water is not used as drinking water or for irrigation, whereas P13 is used only for irrigation for salt tolerant crops and forage plants. It is worth to note that from time to time, local health authorities carry out awareness campaigns to inform the public about the treatment of well water prior to its use as drinking water. And most people declare boiling water prior to consumption, but this is effective for eliminating bacterial contaminations and not for other chemical contaminants. Two main sampling campaigns were conducted, the first one during the wet period, March-April 2016 and the second during the dry period, July-August 2016. In the field, the temperature, the $\mathrm{pH}$ were measured using $\mathrm{pH}$-meter portable (VWR), the electrical conductivity $(E C)$ was measured with a portable conductivity meter (COND 330i / SET), and a piezometric levels by piezometric probe. Two samples has been collected from the same place, one collected for bacteriological analysis in sterile glass bottles, and the second one for chemical analysis in $500 \mathrm{~cm}^{3}$ polyethylene bottles, which were well washed in laboratory with the distilled water, and cleaned several times by the pumped water before sampling. All water samples were immediately cooled to $4^{\circ} \mathrm{C}$ in portable icebox and transferred to the laboratories. The chemical analysis for major ions were performed by protocols described as follows:

- the nitrate and nitrite $\left(\mathrm{NO}_{3}{ }^{-}\right.$and $\left.\mathrm{NO}_{2}{ }^{-}\right)$were determined colorimetrically by continuous flow analysis (Skalar method) [ISO 13395];

- the ammoniacal nitrogen $\left(\mathrm{NH}_{4}^{+}\right)$was determined colorimetrically by continuous flow analysis (Skalar method) [ISO 11732];

- the orthophosphate $\left(\mathrm{H}_{2} \mathrm{PO}_{4}^{-}\right)$was determined by continuous flow analysis (CFA) cited in AFNOR [ISO 15681-2].

The bacteriological analysis was performed immediately after sampling in the provincial laboratory of envi ronmental hygiene of Berkane. The analysis includes: total coliforms (TC), faecal coliforms (FC) and faecal streptococci (FS) according to norms ISO 9308-1, ISO 9308-1 and ISO 7899-2 respectively:

- enumeration of total coliform bacteria per $100 \mathrm{~cm}^{3}$, using the membrane filtration $(0.45 \mu \mathrm{m})$ and culture on Tergitol agar TTC 7 agar $24 \mathrm{~h}$ at $37^{\circ} \mathrm{C}$;

- enumeration of faecal coliform bacteria per $100 \mathrm{~cm}^{3}$, using membrane filtration $(0.45 \mu \mathrm{m})$ and culture on Tergitol agar TTC 7 agar $24 \mathrm{~h}$ at $44^{\circ} \mathrm{C}$;

- enumeration of faecal streptococci bacteria per $100 \mathrm{~cm}^{3}$, using membrane filtration $(0.45 \mu \mathrm{m})$ and culture on Slanetz Bartley agar $24-48 \mathrm{~h}$ at $37^{\circ} \mathrm{C}$.

Some results are presented by thematic maps, using geographical information system (GIS). Mapping of the piezometric levels was performed by Surfer v14 software. It is worth to note that during the field surveys, we noticed that many rural areas were not supplied with drinking water and others did not have accessibility to any sewer network. Thus, the wastewater was discharged into ground via septic tanks and in some cases was discharged to the soil surface which may results in serious public health concerns.

\section{RESULTS AND DISCUSSION}

\section{PHYSICAL AND CHEMICAL PARAMETERS}

\section{Electrical conductivity $(E C)$}

The current levels of the groundwater salinity of Triffa Plain, and their intra-annual variability during the year 2016 were assessed by measuring the $E C$ which provides information on the degree of mineralization of the waters. The $E C$ values ranged between 800 and $8940 \mu \mathrm{S} \cdot \mathrm{cm}^{-1}$ during the wet period (Fig. 3a) and between 900 and 9100 $\mu \mathrm{S} \cdot \mathrm{cm}^{-1}$ during the dry period (Fig. $3 \mathrm{~b}$ ).

The high mineralization rates are related to the lithological nature of the reservoir which is strengthened by the effect of intensive irrigation in several areas of the plain, on both sides of the Hassi-Smia flexure [FEKKOUL et al. 2013]. The highest levels of $E C$ were recorded near the Ouled Mansour hills, as in the spring water of Ain-Zebda (S21) and the well (P30) with an EC recorded of ca. 8300 $\mu \mathrm{S} \cdot \mathrm{cm}^{-1}$ and $9100 \mu \mathrm{S} \cdot \mathrm{cm}^{-1}$ respectively during the dry period. The well (P35), representing the zone situated to the North-East of Berkane measured $7590 \mu \mathrm{S} \cdot \mathrm{cm}^{-1}$ during the same period. In Slimania, Madagh, and going towards outlet sources of Ain-Beida (S17) and Ain-Zerga (S18), situated in the North-West of the plain, and in the area in the North of Café Maure, the EC ranged from 3000 to 5700 $\mu \mathrm{S} \cdot \mathrm{cm}^{-1}$.

In contrast, the $E C$ below $2700 \mu \mathrm{S} \cdot \mathrm{cm}^{-1}$ were recorded in the area parallel to the Cheraa River, Café Maure, the area located at North-West of Ahfir and in the Reggada zone (P37) with an $E C$ ranging from $800 \mu \mathrm{S} \cdot \mathrm{cm}^{-1}$ to 900 $\mu \mathrm{S} \cdot \mathrm{cm}^{-1}$ which represented the lowest salinity recorded in the study.

\section{Nitrate, nitrite, ammonium and orthophosphate concentrations}

Phosphorus and nitrogen are macronutrient that plays an important role in improving agricultural production. World consumption of fertilizers is estimated at ca. $85 \mathrm{mln} \mathrm{t}$ of nitrogen and $15 \mathrm{mln} t$ of phosphorus [RoY et al. 2006]. By 2020, the consumption of mineral fertilizers will reach $114 \mathrm{mln} t$ of nitrogen fertilisers and $21 \mathrm{mln} t$ of phosphorus per year [BUMB, BAANANTE 1996]. It is worth to note that Moroccan consumption of nitrogen fertilizers is estimated at ca. $51 \mathrm{~kg} \cdot \mathrm{ha}^{-1}$ [WANZALA 2007].

Triffa Plain is one of the most important and productive agricultural areas in Morocco. This region is well known by intensive agricultural systems, producing citrus, industrial crops such as sugar beet, conventional crops such as cereals, vegetables and forage crops. Farmers use different fertilizers such as ammonium nitrate $33.5 \%$, mono ammonium phosphate (MAP), ammonium sulphate, super triple phosphate, potassium sulphate, NPK (18, 46, 0 $\mathrm{kg}$ ) and Solupotasse. Such use of fertilizers has led to the 

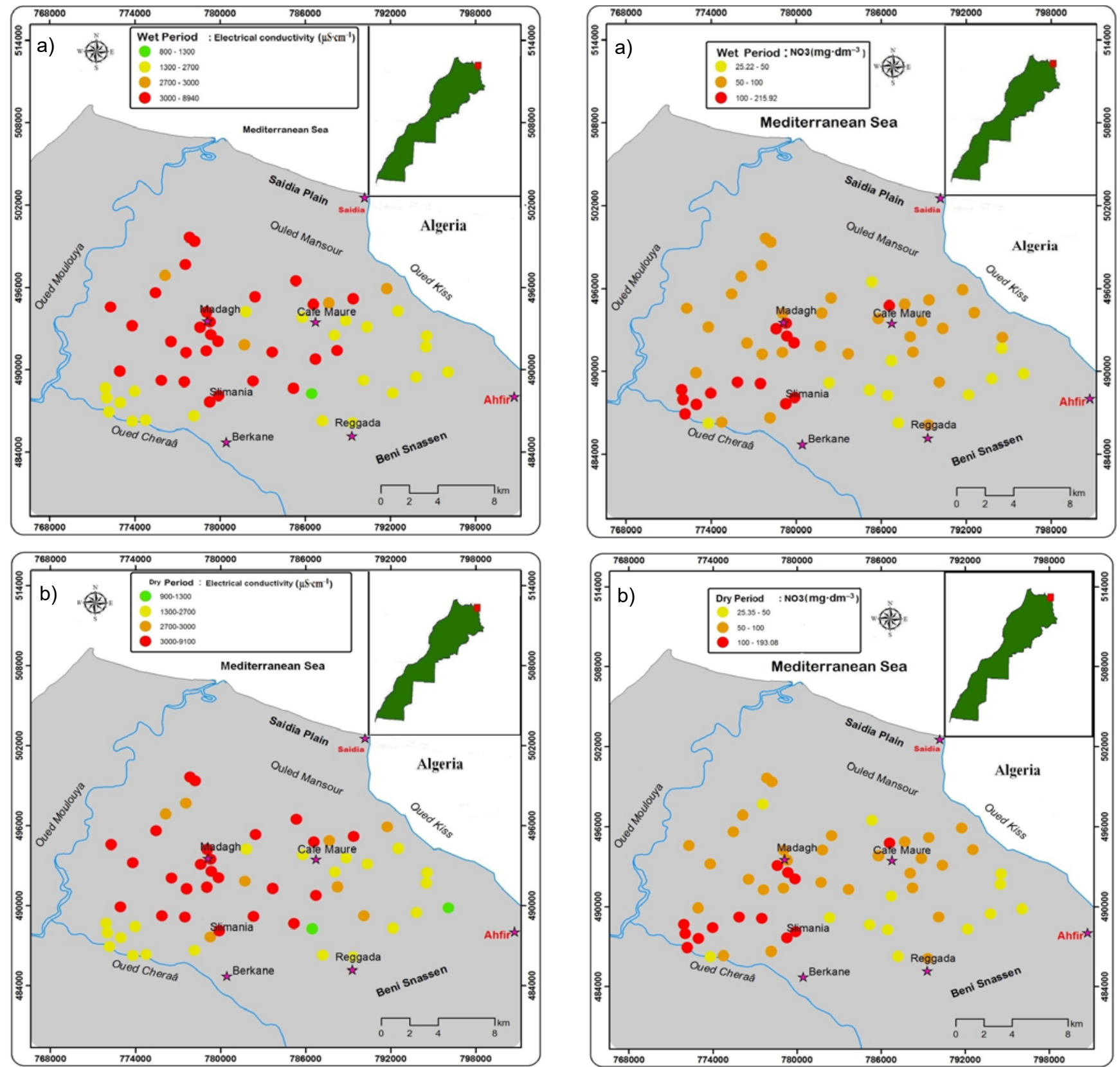

Fig. 3. Spatial variation of electrical conductivity $\left(\mu \mathrm{S} \cdot \mathrm{cm}^{-1}\right)$ in groundwater of Triffa Plain during: a) the wet period 2016,

b) the dry period 2016; source: own study

pollution of the groundwater in this region. This study evaluates the nitrate level and assesses its impact on the quality of the groundwater taking into consideration time and space.

Nitrate.The nitrate levels in the unconfined aquifer varied from 25 (well P48) to $216 \mathrm{mg} \cdot \mathrm{dm}^{-3}$ (well P11) during wet period 2016 (Fig. 4a) and from 25 (well P48) to $193 \mathrm{mg} \cdot \mathrm{dm}^{-3}$ (well P11) during dry period 2016 (Fig. 4b). In $78 \%$ of the samples, the registered values exceeded the critical level of $50 \mathrm{mg} \cdot \mathrm{dm}^{-3}$ as fixed by standards of the World Health Organization (WHO) for drinking water.

The spatial variation maps of nitrate in groundwater of Triffa Plain (Fig. 4) showed that the highest levels of nitrates contamination of the groundwater were observed for the study area in south-western part of Slimania and bor-

Fig. 4. Spatial variation of nitrate $\left(\mathrm{mg} \cdot \mathrm{dm}^{-3}\right)$ in groundwater of Triffa Plain during: a) the wet period 2016,

b) the dry period 2016; source: own study

dering areas of the Cheraa River, for the springs in the north-western area (Ain-Beida S17, Ain-Zerga S18, and Ain-Zebda S21), in the north-eastern area (Café Maure), and in the centre part of the aquifer (Madagh). In all other areas, in the South of the plain with the wells: P35, P38, P36, P37 and P46, and in south-eastern part of the plain, in the zone situated between Reggada and Ahfir, the concentrations of nitrate recorded ranged between 25 and 45 $\mathrm{mg} \cdot \mathrm{dm}^{-3}$.

During the year 2016, $24.5 \%$ of samples showed nitrate concentrations superior to $100 \mathrm{mg} \cdot \mathrm{dm}^{-3}, 53.6 \%$ of samples had concentrations ranging from 50 to 100 $\mathrm{mg} \cdot \mathrm{dm}^{-3}$, and in $21.8 \%$ of samples the concentrations were below $50 \mathrm{mg} \cdot \mathrm{dm}^{-3}$. 
By comparing the spatial distribution map of nitrate with that of piezometric levels (wet period 2016) - (Fig. 5), it will be noted that the zones of high contamination by nitrates, are generally either with shallow water depths, or with more permeable soil.

The nitrate concentrations of groundwater in each sampling point, either well or spring water, varied generally dependent on the wet or the dry period (Fig. 6). They decreased in $73 \%$ of samples (40 wells or springs) during the dry period 2016, by values ranging from 0.5 to 35 $\mathrm{mg} \cdot \mathrm{dm}^{-3}$, while they increased in $27 \%$ of cases (15 samples) by values ranging from 0.13 to $13 \mathrm{mg} \cdot \mathrm{dm}^{-3}$ except for the well P53 where this value reached $43.9 \mathrm{mg} \cdot \mathrm{dm}^{-3}$. The rise of nitrate concentration in groundwater can be explained by the fact that due to precipitations during the wet period, the nitrate is highly leached into the deeper layers of soil and then to groundwater in one hand and as consequence to the use of mineral and organic fertilizers during this period.

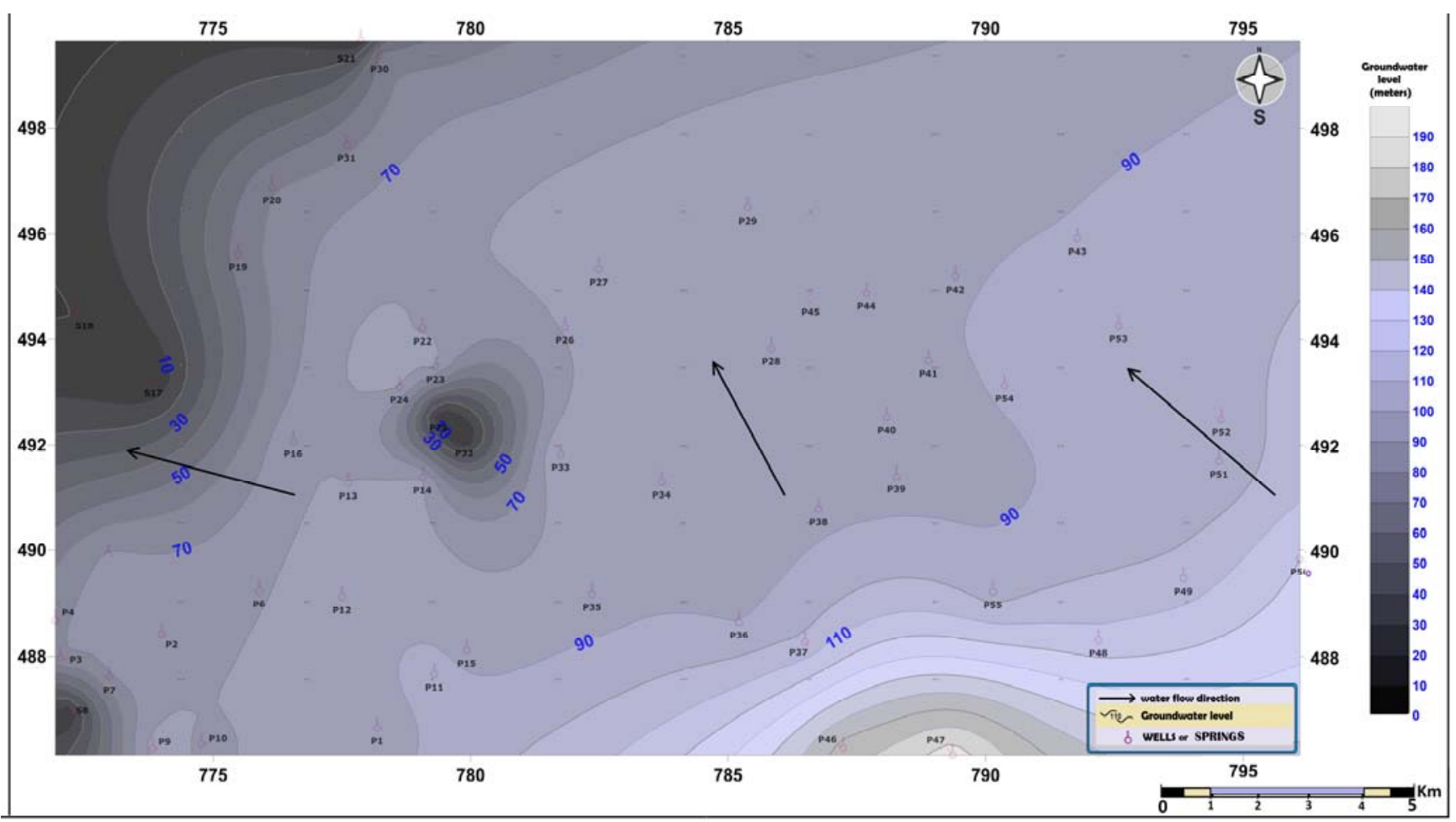

Fig. 5. Map of piezometric levels (in m above the average sea level) and flow vectors, Triffa Plain, wet period 2016; source: own study

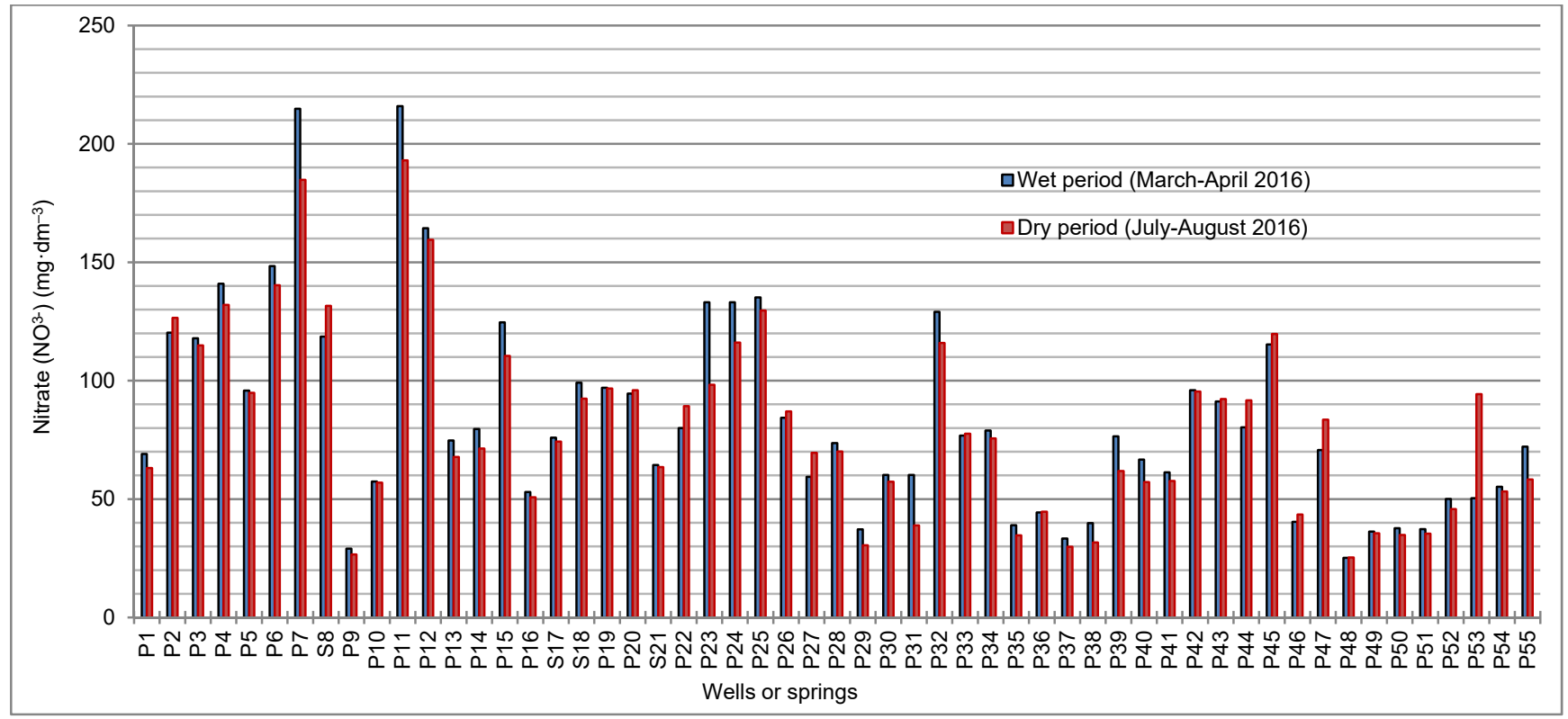

Fig. 6. Variation of nitrate concentration in groundwater sampled during wet and dry periods 2016; P1-P55 = sampling points as in Fig. 2; source: own study 
However in dry period, in areas where the water table is near to the soil surface or where the soil is more permeable, and the irrigation is gravitational and intense as in the case of some abundant late vegetable cultures which receive high quantities of nitrogen fertilizers, the leaching of nitrates is also important as in the case of wet period. This might be one of the reasons for the slight augmentation of their concentrations recorded in $27 \%$ of samples.

The result reported herein shows that nitrate concentration levels in Triffa Plain groundwater rose continuously from 1997 up today as reported by BENKADDOUR [1997], FETOUANi et al. [2008], FEKKOUL et al. [2013] and YAHYA et al. [2015].

This increasing nitrate pollution is most probably due to the increase in the quantities of nitrogen fertilizers and manure used to increase the agricultural productivity to meet the need of the growing population. Indeed, from the year 2000 until 2016, the surfaces of citrus fruits have passed from 11205 ha to 17229 ha, the vegetable crops surfaces rose from 5548 ha to 6296 ha and the surface of industrial crops of which sugar beet roses from 1003 ha to 1645 ha [ORMVAM 2016].

Nitrite. Nitrite is the ionic intermediate state between nitrate and ammonia nitrogen, which explains their low quantities encountered in the aquatic environment. Nitrites result from an incomplete oxidation of organic matter.Their high levels are due to agricultural runoff, refuse dump runoff or contamination with human or animal wastes where the nitrate is reduced to give nitrite by sulphite-reducing anaerobic bacteria. They can also be related to the bacterial oxidation of ammonia [BENGOUMI et al. 2004]. In this study, we report that nitrites content of groundwater samples from Triffa Plain area during the wet period did not exceed the normal rate set at $0.1 \mathrm{mg} \cdot \mathrm{dm}^{-3}$ by WHO for drinking water, except for the wells P6, P20 and $\mathrm{P} 55$ where values were $0.14,0.27$ and $0.9 \mathrm{mg} \cdot \mathrm{dm}^{-3}$ respectively. During the dry period, the nitrite concentrations observed were below $0.04 \mathrm{mg} \cdot \mathrm{dm}^{-3}$ for all samples except for the well P35 where concentration was $0.24 \mathrm{mg} \cdot \mathrm{dm}^{-3}$. The nitrite concentration reported herein were generally slightly higher than those reported by FETOUANI et al. [2008] concerning the groundwater of the Triffa Plain where nitrite concentrations ranged from 0.0009 and 0.13 $\mathrm{mg} \cdot \mathrm{dm}^{-3}$

Ammonium. Most ammonium concentrations were below $0.02 \mathrm{mg} \cdot \mathrm{dm}^{-3}$ during the wet period except for the wells P52, P53, P47, P35, P50, P54, P48, P51 where the concentrations were higher, but did not exceed the limit set by WHO for drinking water, with values of $0.06,0.09$, $0.10,0.14,0.16,0.20,0.25,0.32 \mathrm{mg} \cdot \mathrm{dm}^{-3}$ respectively. The content of ammonium recorded in this study was slightly higher than those reported by FETOUANI et al. [2008] about the same region. During the dry period all wells showed ammonium concentrations below 0.02 $\mathrm{mg} \cdot \mathrm{dm}^{-3}$. The absence of ammonia nitrogen usually reflects a process of high level of biodegradability by using biological processes like the nitrification-denitrification process [GRADY et al. 2011; SKRZYPIEC, GAJEWSKA 2017; WEF 2005] which leads to ammonia nitrogen removal. It has to be noted as well that the ammonium may be partial- ly fixed in the soil and does not contaminate groundwater [ERSKINE 2000].

Orthophosphates. The orthophosphate concentrations found in wells and spring waters samples were below 0.02 $\mathrm{mg} \cdot \mathrm{dm}^{-3}$, except for the well P55 where the concentration was $0.24 \mathrm{mg} \cdot \mathrm{dm}^{-3}$ during the wet period and the well P30 where the concentration was $0.19 \mathrm{mg} \cdot \mathrm{dm}^{-3}$ during the dry period.

These values, below the maximum allowable value by WHO for drinking water, can be explained by the fact that orthophosphates are easily fixed by the soil, mainly by iron oxides and aluminium [HALIM et al. 2009].

\section{RESULTS OF BACTERIOLOGICAL ANALYSIS}

The most frequent type of groundwater contamination in rural areas is faecal pollution. The latter is due to livestock, inadequate human waste disposal systems [BARNES, GORDON 2004; CONBOY, Goss 2001] and to various other sources [MAHLER et al. 2000]. It is important to evaluate this faecal contamination, especially if this groundwater is used for domestic purpose without any treatment systems [ATHERHOLT et al. 2003].

In addition to its agricultural wealth, the Triffa Plain is habitat for a large rural population represented by inhabitants scattered along the boundaries of farms or grouped in small villages or towns. Despite the efforts of the state to provide this population with drinking water during the last decade, there are still many homes without access to this source of life. This forces a large part of rural population to rely on raw groundwater (springs or wells) for its drinking and domestic water supply.

The lack of sewage networks, even in some towns, forces the population to install septic tanks. The latter are sometime located too close to a drinking water well and thus bacteriological, viral and parasitic contaminants from the wastewater can end up in drinking water that put the public's health at risk. In the rural commune of Madagh, which is constituted by 13 locations of 12096 inhabitants spread over an area of $120 \mathrm{~km}^{2}$, only $19 \%$ of the population and $8 \%$ of locations are connected to the sewage system. Whereas in the town Café Maure of a surface of 109 $\mathrm{km}^{2}$ and 11765 inhabitants, and in the other areas of the Triffa Plain, as Slimania and bordering areas of the Cheraa River, the wastewater facilities are absent [PCD 2012 2016]. Thus, it was important to study the Triffa groundwater microbiology.

Apart few exceptions, the faecal pollution indicators are not hazardous, but their presence in groundwater is a sign of probable contamination by dangerous pathogenic bacteria for human health. Indeed, the presence of faecal coliforms may indicate the presence of enteropathogenic microorganisms, such as Salmonella and Norwalk virus [CRAUN et al. 2002]. In Morocco, waterborne diseases are one of the leading causes of death among children, particularly in rural areas (45\% of total population) [LAHBABI, ANOUAR 2010]. Thus, it is necessary to assess the rate of contamination and to evaluate the importance of different factors of pollution.

In regard to faecal pollution indicators, the results of bacteriological study of selected groundwater samples (55 wells 
and springs) sampled in wet and dry period are presented by GIS maps.

Total coliforms (TC). Almost all sampled wells and springs were contaminated with TC. Their quantities differed between wells and water springs, and depended on the sampling period, wet or dry. We noticed that the rate of TC increased during the dry period. During the wet period of 2016, TC values varied from $0 \mathrm{CFU} \cdot\left(100 \mathrm{~cm}^{3}\right)^{-1}$ in wells and spring waters (S17, S18, P37 and P54) and 9000 CFU. $\left(100 \mathrm{~cm}^{3}\right)^{-1}(\mathrm{P} 50)-($ Fig. $7 \mathrm{a})$, with an average of 708.5 $\mathrm{CFU} \cdot\left(100 \mathrm{~cm}^{3}\right)^{-1}$, whereas during the dry period of the same year, the TC values varied from $0 \mathrm{CFU} \cdot(100$ $\left.\mathrm{cm}^{3}\right)^{-1}(\mathrm{P} 55)$ and $14000 \mathrm{CFU} \cdot\left(100 \mathrm{~cm}^{3}\right)^{-1}(\mathrm{P} 36)-($ Fig. $7 \mathrm{~b})$ with an average of $1500 \mathrm{CFU} \cdot\left(100 \mathrm{~cm}^{3}\right)^{-1}$.

Faecal coliforms (FC). FC are indicators of faecal contamination and are also present in almost all sampled wells and springs. Their rates were higher during the dry period and in general, their quantities are less when compared to the TC.

During the wet period, FC values ranged between 0 CFU $\left(100 \mathrm{~cm}^{3}\right)^{-1}$ in springs and the wells (P6, P12, S17, $\mathrm{S} 18, \mathrm{P} 25, \mathrm{P} 37, \mathrm{P} 39, \mathrm{P} 48, \mathrm{P} 54)$ and $3550 \mathrm{CFU} \cdot\left(100 \mathrm{~cm}^{3}\right)^{-1}-$ (P35) (Fig. 8a), with an average of $270 \mathrm{CFU} \cdot\left(100 \mathrm{~cm}^{3}\right)^{-1}$, whereas during the dry period the $\mathrm{FC}$ values ranged between $0 \mathrm{CFU} \cdot\left(100 \mathrm{~cm}^{3}\right)^{-1}-(\mathrm{P} 55)$ and 5000 CFU $\left(100 \mathrm{~cm}^{3}\right)^{-1}-(\mathrm{P} 11$ and P36) (Fig. 8b), with an average of $637.5 \mathrm{CFU} \cdot\left(100 \mathrm{~cm}^{3}\right)^{-1}$.
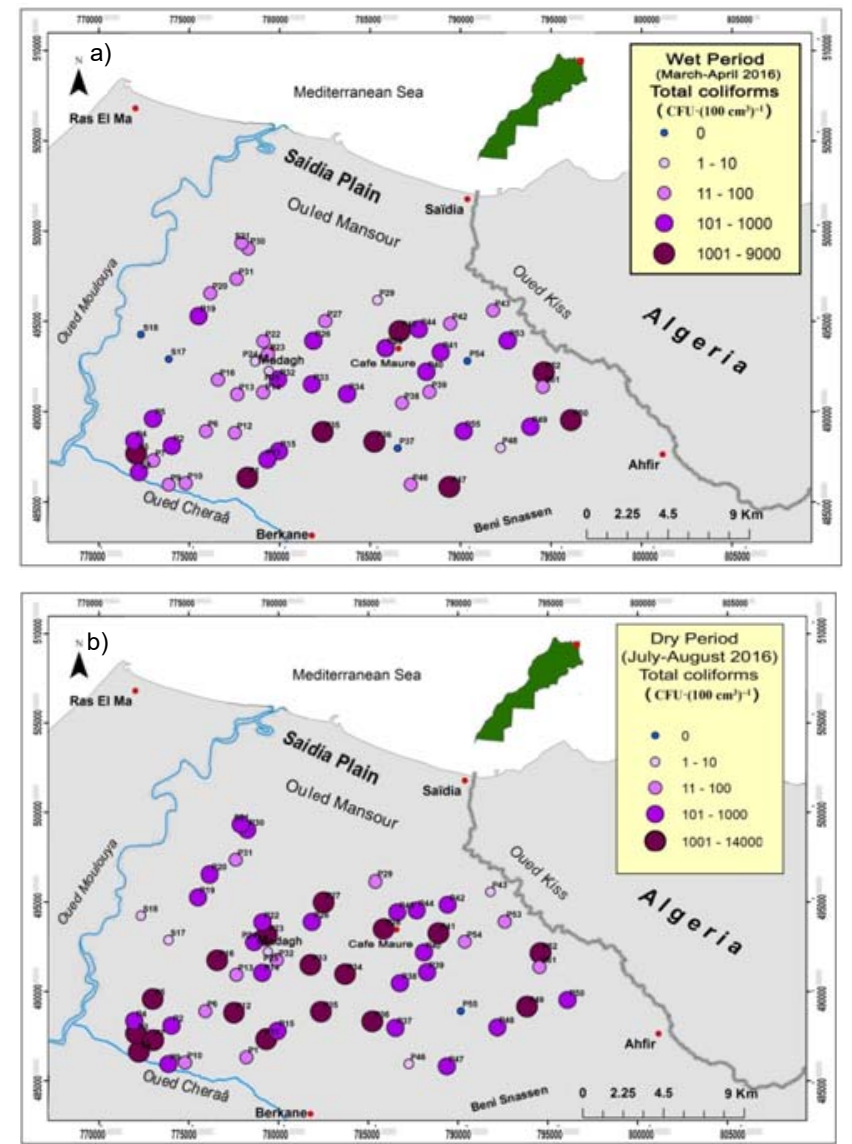

Fig. 7. Distribution of total coliforms concentrations (CFU. $\left.\left(100 \mathrm{~cm}^{3}\right)^{-1}\right)$ in groundwater of Triffa Plain sampled during: a) the wet period 2016, b) the dry period 2016; source: own study
Faecal streptococci (FS). FS are indicators of faecal contamination and are also present in almost all wells and water springs, but generally with smaller rates than FC. In wet period, FS values ranged between $0 \mathrm{CFU} \cdot\left(100 \mathrm{~cm}^{3}\right)^{-1}$ - (P12, P14, S17, S18, P25, P37 and P44) and 5000 CFU. $\left(100 \mathrm{~cm}^{3}\right)^{-1}-(\mathrm{P} 35)$ (Fig. 9a), with an average of 216.9 CFU $\left(100 \mathrm{~cm}^{3}\right)^{-1}$. In dry period, the FS values varied between $0 \mathrm{CFU} \cdot\left(100 \mathrm{~cm}^{3}\right)^{-1}-(\mathrm{P} 6, \mathrm{~S} 17, \mathrm{~S} 18, \mathrm{P} 25, \mathrm{P} 31$, $\mathrm{P} 38$, and P55) and $2000 \mathrm{CFU} \cdot\left(100 \mathrm{~cm}^{3}\right)^{-1}-(\mathrm{P} 36)$ (Fig. $9 b)$, with an average of $146.2 \mathrm{CFU} \cdot\left(100 \mathrm{~cm}^{3}\right)^{-1}$.

Almost all groundwater of unconfined aquifer of Triffa Plain sampled in this study showed a bacteriological contamination during the wet and the dry periods, with seasonal variation in the concentration of bacteria indicators as result of faecal pollution except for the spring waters Ain-Beida (S17), Ain-Zerga (S18) and well (P37) during the wet period and well (P55) during the dry period, where no contamination was recorded. The presence of both FC and FS provided strong evidence of faecal contamination [ATHERHOLT et al. 2003] which was probably due to the infiltrations of wastewater produced by human and/or animal. These results indicated the deterioration of groundwater quality.

The growing population and the multiplication of slums along the rural areas, without any urban plan, generate a proliferation of septic tanks systems as the only sewage facilities what cause the increase of the contamination
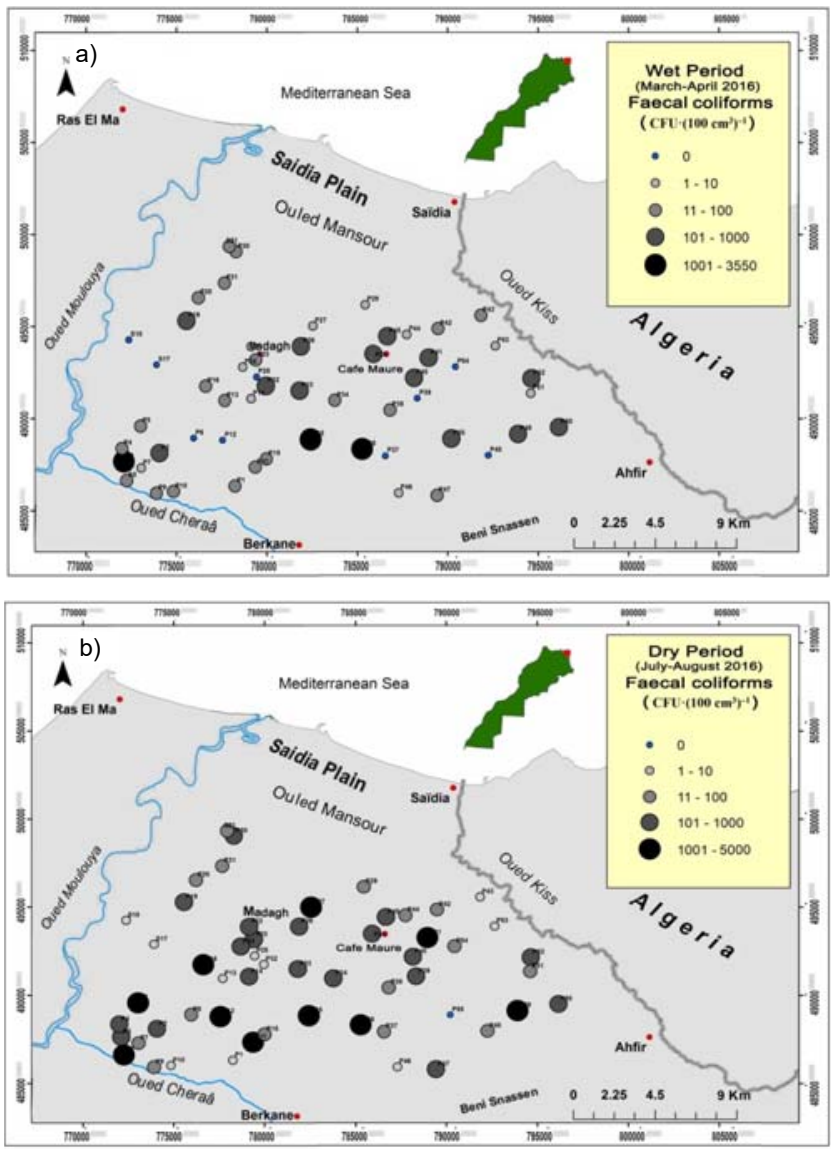

Fig. 8. Distribution of faecal coliforms concentrations (CFU $\left.\cdot\left(100 \mathrm{~cm}^{3}\right)^{-1}\right)$ in groundwater of Triffa Plain sampled during: a) the wet period 2016, b) the dry period 2016; source: own study 

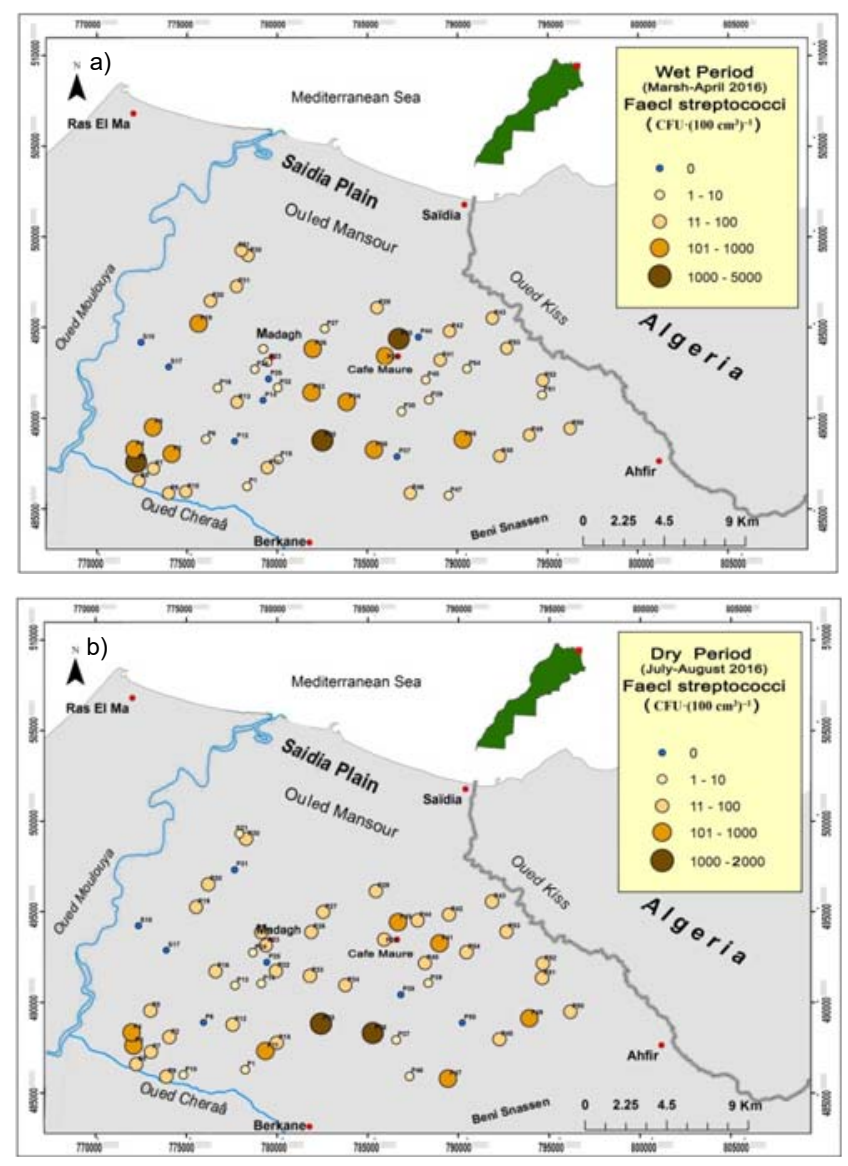

Fig. 9. Distribution of faecal streptococci concentrations (CFU $\left.\cdot\left(100 \mathrm{~cm}^{3}\right)^{-1}\right)$ in groundwater of Triffa Plain sampled during: a) the wet period 2016 , b) the dry period 2016; source: own study

of the groundwater. This is the case of several locations of rural communes of Triffa Plain, such as Café Maure, Madagh and the South-West area of Triffa Plain where almost all wells and springs have high FC concentrations. The values varied from 11 to $3550 \mathrm{CFU} \cdot\left(100 \mathrm{~cm}^{3}\right)^{-1}$ during the wet period whereas in dry period the concentrations were greater and varied from 100 to $5000 \mathrm{CFU} \cdot\left(100 \mathrm{~cm}^{3}\right)^{-1}$. Also, the FS concentrations ranged from 11 to 5000 $\mathrm{CFU} \cdot\left(100 \mathrm{~cm}^{3}\right)^{-1}$ in wet period and from 11 to 1000 CFU $\left(100 \mathrm{~cm}^{3}\right)^{-1}$ in dry period. These high levels of indicators of faecal contamination of groundwater in these areas were mainly due to domestic wastewater and to the use of manure by farmers. In addition, raw sewage is dumped untreated into the Cheraa River which may contaminate groundwater by infiltration in adjacent areas. Adding to this the shallow depths of the aquifer at these levels facilitate this contamination.

In deep wells situated far from towns (P35 and P36) as in the South and South-East of the plain, the high contamination can have other origins. Their high levels of contamination by FC and FS during the two periods of sampling were probably due to the fact that these wells were mainly exposed to direct contamination by the waste of livestock and avifauna through the mouth of the wells. The concentrations of TC and FC increased in the dry period as result of the rise in temperature and nutrients which promoted their multiplication, whereas the concentration of FS de- creased during the same period. Persistence of bacteria in the aquatic environment depends on various parameters, such as nutrients and temperatures [LECLERC et al. 2002]. The prevalence of FS, with rapid die-off, showed either recent contamination by faecal material or high level of contamination possibly associated with organic matter [CONBOY et al. 2001].

\section{CONCLUSIONS}

Water quality is managed and assessed in terms of bacteria indicators levels and physico-chemical characteristics. The results obtained, showed that groundwater quality of Triffa aquifer becomes deteriorated. The contaminations of wells and spring waters by nitrates during the wet and the dry periods showed that their levels exceed the standard value fixed by WHO for drinking water in ac. $78 \%$ of samples. Furthermore, the nitrate contamination of groundwater increased during the wet period in $73 \%$ of cases as result of leaching by rainfall and irrigation during this period of high agricultural activity. The deterioration of the groundwater quality of Triffa Plain is also characterized by the salinization phenomena. Indeed, the monitoring of electrical conductivity showed that the groundwater was well mineralized.

The investigation showed also that almost all wells and springs were contaminated by bacteriological factors such as TC, FC or FS. We suspected that intensive irrigated agriculture was the main cause of the diffuse nitrate pollution as result of excessive and repeated application of chemical nitrogen fertilizers and manure, whereas, the groundwater contamination by faecal germs was the result of untreated sewage septic tanks or animal wastes. It should also be noted that the presence of stables of cattle, sheep and avifauna and the use of their waste as fertilizer can lead to contamination of groundwater, by nitrates and pathogenic bacteria, especially in areas with shallow groundwater.

Local authorities should monitor at regular intervals the level of contamination and point out any contaminated well or spring not fit for human ingestion and advise the local population on the risks associated with the consumption of such contaminated water. They also should secure drinking water supply for the population living in this area in order to avoid any health concerns.

\section{REFERENCES}

Atherholt T., Feerst E., Hovendon B., KwaK J., Rosen J.D. 2003. Evaluation of indicators of faecal contamination in groundwater. Journal American Water Works Association. Vol. 95. No. 10 p. 119-131.

Avery A.A. 2001. Cause of methemoglobinemia: Illness versus nitrate exposure. Environmental Health Perspectives. Vol. 109. No. 1 p. $12-14$.

BARnes B., Gordon D.M. 2004. Coliform dynamics and the implications for source tracking. Environmental Microbiology. Vol. 6 p. 501-509.

Bengoumi M., Traoure A., Bouchriti N., Bengoumi D., El HRAIKI A. 2004.Qualité de l'eau en aviculture [Poultry water quality]. Revue trimestrielle d'information scientifique et technique. Vol. 3. No. 1 p. 5-29. 
BEnKADDOUR R. 1997. Contribution à l'étude de la salinité et de la pollution par les nitrates des eaux souterraines de la plaine des Triffa "Basse Moulouya"[Study of salinity and nitrates pollution on the groundwater of the Triffa plain "Low Moulouya"]. Oujda. Université Mohammed Premier pp. 100.

BoughriBA M., JiLALI A. 2018. Climate change and modeling of an unconfined aquifer: the Triffa plain, Morocco. Environment Development and Sustainability. Vol. 20. No. 5 p. 2009-2026.

BuMB B.L., BAANANTE C.A. 1996. World trends in fertilizer use and projections to 2020. Washington, DC. International Food Policy Research Institute. Brief 38 pp. 4.

BZIOUI M. 2004. Rapport national 2004 sur les ressources en eau au Maroc [National report 2004 on Water Resources in Morocco]. UN Water-Africa pp. 94.

ConBoy M.J., Goss M.J. 2001.Identification of an assemblage of indicator organisms to assess timing and source of bacterial contamination in groundwater. Water, Air, and Soil Pollution. Vol. 129 p. 101-118.

Craun G.F., Nwachuku N., Calderon R.L., Craun M.F. 2002.Outbreaks in drinking-water systems, 1991-1998. Journal of Environmental Health. Vol. 65 p. 16-25.

El Haissoufi H., Berrada S., Merzouki M., Aabouch M., Bennani L., Benlemlih M., Idir M., Zanibou A., Bennis Y., El Ouali Lalami A. 2011. Pollution des eaux de puits de certains quartiers de la ville de Fès, Maroc [Pollution of well water in some districts of Fes city, Morocco]. Revue de Microbiologie Industrielle Sanitaire et Environnementale. Vol. 5. No. 1 p. 37-68.

El Hammoumi N., Sinan N., Lakhlif B., LaKhdar M. 2013. Use of multivariate statistical and geographicinformation system (GIS)-based approach to evaluateground water quality in the irrigated plain of Tadla (Morocco). International Journal of Water Resources and Environmental Engineering. Vol. 5 No. 2 p. 77-93.

El Mandour A. 1998. Contribution hydrogéologique de la plaine des Triffa. Salinisation et modélisation [Hydrogeologic contribution of Triffa plaine. Salinisation and modelisation]. PhD Thesis. Oujda. University Mohamed Premier pp. 206.

ERSKINE A.D. 2000. Transport of ammonium in aquifers: retardation and degradation. Quarterly Journal of Engineering Geology and Hydrogeology. Vol. 33 p. 161-170.

Fekkoul A., Zarhloule Y., Boughriba M., Barkaoui A.E., JILALI A., BOURI S. 2013. Impact of anthropogenic activities on the groundwater resources of the unconfined aquifer of Triffa plain (eastern Morocco). Arabian Journal of Geosciences. Vol. 6 p. 4917-4924.

Fetouani S., Sbaa M., Vanclooster M., Bendra B. 2008. Assessing ground water quality in the irrigated plain of Triffa (north-east Morocco). Agricultural Water Management. Vol. 95 p. 133-142.

Freishtat R.J., Chamberlain J.M., Johns C.M.S., Teach S.J., RonZio C., Murphy-SMith M.M., Gor N. 2005. A crosssectional ED survey of infantile subclinical methemoglobinemia. American Journal of Emergency Medicine. Vol. 23. No. 4 p. $574-576$.

Grady C.P.L, Daigger G.T, Love N.G., Filipe C.D.M. 2011. Biological wastewater treatment. $3^{\text {rd }}$ ed. London. IWA Publishing. ISBN 0849396794 pp. 1022.

Halim MA., Majumder R.K., NesSA S.A., Hiroshiro Y., UdDiN MJ., SHIMADA J., JiNNO K. 2009. Hydrogeochemistry and arsenic contamination of groundwater in the Ganges Delta Plain, Bangladesh. Journal of Hazardous Materials. Vol. 164 p. 1335-1345.

Hassoune El M., Bouzidi A., Koulali Y., Hadarbach D. 2006. Effets des rejets liquides domestiques et industriels sur la qualité des eaux souterraines au nord de la ville de Settat
(Maroc) [Effects of domestic and industrial liquid discharges on the quality of groundwaternorth of the city of Settat (Morocco)]. Bulletin de l'institut Scientifique, Rabat. Sect. Sciences de la Vie. Vol. 28 p. 61-71.

Hassoune El M., El KetTani S., Koulali Y., Bouzidi A. 2010. Contamination bactériologique des eaux souterraines par les eaux usées de la ville de Settat [Bacteriological contamination of groundwater by Settat city wastewater]. Revue de Microbiologie Industrielle Sanitaire Et Environnementale. Vol. 4. No. 1 p. $1-21$.

ISO 7899-2: 2000.Water quality - Detection and enumeration of intestinal enterococci - Part 2: Membrane filtration method.

ISO 9308-1: 2000. Water quality - Detection and enumeration of Escherichia coli and coliform bacteria - Part 1: Membrane filtration method.

ISO 11732: 2005. Water Quality - Determination of ammonium nitrogen - Flow analysis method (CFA and FIA) and spectrometric detection.

ISO 13395: 1996. Water Quality - Determination of nitrite nitrogen and nitrate nitrogen and the sum of both by flow analysis (CFA and FIA) and spectrometric detection.

ISO 15681-2:2003. Water quality - Determination of orthophosphate and total phosphorus contents by flow analysis (FIA and CFA) - Part 2: Method by continuous flow analysis (CFA).

Kelmendi M., Kadriu S., Sadiku M., Aliu M., Sadriu E., HYSENI S.M. 2018. Assessment of drinking water quality of Kopiliq village in Skenderaj, Kosovo. Journal of Water and Land Development. No. 39 p. 61-65. DOI 10.2478/jwld2018-0059.

Laftouhi N.E., Vanclooster M., Jalal M., Witam O., AbouFIRASSI M., BAhIR M., Persoons E. 2003. Groundwater nitrate pollution in the Essaouira Basin (Morocco). Comptes Rendus Geoscience. Vol. 335. Iss. 3 p. 307-317.

LAHBABI A., ANOUAR K. 2010. Evaluation environnementale du projet d'adduction régionale d'alimentationen eau potable [Environmental assessment of regional drinking Water Supply Project]. ONEP report. Rabat. Kingdom of Morocco pp. 64.

Leclerc H., Schwartzbrod L., Dei-Cas E. 2002. Agents microbiens associés aux maladies hydriques [Microbials agents associated with waterborne diseases]. Critical Reviews in Microbiology. Vol. 28. No. 4 p. 371-409.

Mahler B.J., Personne J.C., Lods G F., Drogue C. 2000. Transport of free and particulate associated bacteria in karst. Journal of Hydrology. Vol. 238 p. 179-193.

MATEE 2001. Rapport sur l'état de l'environnement du Maroc [Report on the state of the environment in Morocco]. Rabat 2001. Ministère de l'Aménagement du Territoire, de l'Eau et de l'Environnement. Département de l'Environnement Observation National de l'Environnement du Maroc pp. 296.

Melloul A., Amahmid O., Hassani L., Bouhoum K. 2002. Health effect of human wastes used in agriculture in El Azzouzia (the wastewater spreading area of Marrakech city, Morocco). International Journal of Environmental Health Research. Vol. 12. No. 1 p. 17-23.

MEMEE 2014. Etat de la qualité des ressources en eau au Maroc 2009-2012 [State of the quality of water resources in Morocco 2009-2012]. Rabat. Ministère délégué auprès du Ministère de l'énergie des mines, de l'eau et de l'environnement charge de l'eau pp. 42.

ORMVAM 2016. Recensement General des Cultures, Campagne 2015/2016 [General Census of Cultures, Campaign 2015/ 2016]. Berkane. Office Régional de la Mise en Valeur Agricole de la Moulouya pp. 44.

PCD 2012-2016. Plan communal de développement, Commune rurale de Madagh et Commune rurale de Laâtamna [CPD: 
Communal plan for development, rural commune of Madagh, and rural commune of Laâtamna]. Province Berkane. 2012/2016 pp. 60.

Roy R.N., Finck A., Blair G.J., TANDON H.L.S. 2006. Plant nutrition for food security. A guide for integrated nutrient management. FAO Fertilizer and Plant Nutrition Bulletin. No. 16. Rome. Food and Agriculture Organisation pp. 348.

SKRZYPIEC K., GAJEWSKA M.H. 2017. The use of constructed wetlands for the treatment of industrial wastewater. Journal of Water and Land Development. No. 34 p. 233-240. DOI 10.1515/jwld-2017-0058.

Venkateswari R., Ganesh R., DeEnadayalan M., Mahender E., RAMACHANDRAN B., JANAKIRAMAN L. 2007. Transient methemoglobinemia in an infant. The Indian Journal of Pediatrics. Vol. 74. No. 11 p. 1037-1038.

WANZALA M.N. 2007. Implementation of Abuja declaration on fertilizer for an African Green Revolution. NEPAD Second Semi-Annual Progress Report. June 2006-June 2007.
WEF 2005. Biological nutrient removal (BNR) operation in wastewater treatment plants: WEF Manual of Practice. No. 30. ASCE Manual and Reports on Engineering Practice Book 2. Alexandria, Virginia. Water Environment Federation. ISBN 0071464158 pp. 597.

Weyer P.J., Cerhan J.R., Kross B.C., Hallberg G.R., KantaMNENI J., Breuer G., JONes M.P., Zheng W., LYNCH C.F. 2001. Municipal drinking water nitrate level and cancer risk in older women: The Lowa Women's Health Study. Epidemiology. Vol. 12. No. 3 p. 327-338.

Yahya H.S.A., Jilali A., Battioui M., Mostareh M-M-M., Belbachir C., Chafi A. 2015. Seasonal variation of physicochemical and bacteriological characteristics of groundwater using a GIS: Triffa plain (northeast Morocco). Journal of Materials and Environmental Sciences. Vol. 6. No. 9 p. 2400 2408.

\section{Mohammed KADAOUI, Abderrahime BOUALI, Mourad ARABI}

\section{Fizyczna, chemiczna i bakteriologiczna ocena jakości wody gruntowej na nawadnianej Równinie Triffa w północnowschodnim Maroku}

\section{STRESZCZENIE}

Przeprowadzono fizyczną, chemiczną i bakteriologiczną ocenę jakości wód gruntowych, aby wykazać wpływ rolnictwa i innych form działalności człowieka na Równinie Triffa w północnowschodnim Maroku. Poziom zanieczyszczeń oceniono przez analizę przewodnictwa elektrolitycznego, stężeń azotanów i azotynów, jonów amonowych, ortofosforanów oraz wskaźników zanieczyszczeń pochodzenia kałowego.

Próbki wody pobrano z 55 stanowisk dwukrotnie - w czasie pory suchej i deszczowej w 2016 r. Wyniki analiz wskazują, że większość próbek wody była silnie zanieczyszczona. Przewodność elektrolityczna właściwa zmieniała się od 800 do $9100 \mu \mathrm{S} \cdot \mathrm{cm}^{-1}$. Stężenie azotanów (V) wynosiło od 25 do $216 \mathrm{mg} \cdot \mathrm{dm}^{-3}$, a w $78 \%$ próbek stwierdzono stężenie większe niż wartość krytyczna równa $50 \mathrm{mg} \cdot \mathrm{dm}^{-3}$. Stężenie azotanów (III) były nieco większe w porze deszczowej w $73 \%$ badanych przypadków. Stężenie azotanów (III) rzadko przekraczało normy ustalone przez WHO, osiągając maksymalnie 0,90 $\mathrm{mg} \cdot \mathrm{dm}^{-3}$. Stężenie jonów amonowych i ortofosforanów nie przekraczało wartości normatywnych.

Badania wykazały silne skażenie wód podziemnych mikroorganizmami, co przejawiało się dużym zagęszczeniem całkowitym bakterii coli $\left(0-14000 \mathrm{jtk} \cdot\left(100 \mathrm{~cm}^{3}\right)^{-1}\right)$, bakterii coli pochodzenia kałowego $\left(0-5000 \mathrm{jtk} \cdot(100 \mathrm{~cm})^{-1}\right) \mathrm{i} \mathrm{kałowych}$ streptokoków $\left(0-5000 \mathrm{jtk} \cdot\left(100 \mathrm{~cm}^{3}\right)^{-1}\right)$. Wyniki te potwierdzają wpływ osadników gnilnych, dopływu nieoczyszczonych ścieków i stosowania nawozów naturalnych na jakość wód gruntowych.

Słowa kluczowe: czynniki bakteriologiczne, czynniki chemiczne, czynniki fizyczne, jakość wody, Równina Triffa, ścieki, woda gruntowa 